\title{
Dynamic changes of key enzymes activity in a bromate and perchlorate-reducing hydrogen-based membrane biofilm reactor
}

\author{
YuChao Chen ${ }^{1, *}$, YiMing Zhang ${ }^{1}$ and YaMei Han ${ }^{1}$ \\ ${ }^{1}$ Guangxi Key Laboratory of Environmental Pollution Control Theory and Technology, Guilin University of Technology, Guilin 541004, \\ China
}

\begin{abstract}
In this study, the microorganisms in different stages of MBfR were cultured, by using kits to detect the dynamic changes of key enzymes activity, and exploring the effects of biofilm microorganisms on key enzymes activity of MBfR. The results indicated that function or role played by microorganism lived on the outer surface of membrane directly caused the removal of $\mathrm{NO}_{3}{ }^{-} \mathrm{N}, \mathrm{BrO}_{3}{ }^{-}$and $\mathrm{ClO}_{4}{ }^{-}$from water in the $\mathrm{MBfR}$. The key enzymes activity is related to $\mathrm{NO}_{3}{ }^{-}-\mathrm{N}$ and degraded substances. When the concentration of $\mathrm{NO}_{3}{ }^{-}-\mathrm{N}$ is $5 \mathrm{mg} / \mathrm{L}$, the activities of denitrification enzyme were obviously inhibited.
\end{abstract}

\section{Introduction}

Hydrogen-based membrane biofilm reactor (MBfR) is a novel and special membrane bioreactor using $\mathrm{H}_{2}$ as an electron donor to reduce kind of oxidated pollutants from water and wastewater[1-4]. As a clean energy, $\mathrm{H}_{2}$ has the advantages of no pollution and low preparation cost, causing extensive concern[5-7].

Although being successful in dealing with water pollution, MBfR also adversely affects the behavior of hydrogen autotrophic microorganisms. Hyun[8] reported that MBfR can enrich the hydrogen-otrophic methanogens, and inhibit the growth of methanogens in acid operations. The research arouse our interests in the study about of biofilm microorganisms on key enzymes activity of MBfR. However, the effects were still unknown and only little attention was paid to the effects on biofilm microorganisms.

In MBfR, hydrogenotrophic denitrification bacte-ria were generally accounted for the most part of the biofilm microorganisms. Hydrogenotrophic denitrific-ation bacteria can successfully promote MBfR re-moval of oxidized contaminants, such as arsenate[9], chromate[10], nitrate[6], perchlorate[11], selenite[12], trichlorathene[13] and $\mathrm{N}$-nitrosodimethylamine[14]. Therefore, studying the effects of biofilm micro-organisms on MBfR is important, which can benefit to the application of biofilm microorganisms. However, the effect among microbial community and key enzymes activity of MBfR has not been reported. This study is based on MBfR degradation of $\mathrm{NO}_{3}^{-}-\mathrm{N}, \mathrm{BrO}_{3}^{-}$and $\mathrm{ClO}_{4}^{-}$, the effects of biofilm microorganisms on key enzymes activities of MBfR were investigated.

\section{Materials and methods}

\subsection{Experimental setup}

The fiber inner and outer diameters are $1.0 \mathrm{~mm}, 1.5 \mathrm{~mm}$, respectively. The working-volume was $1.8 \mathrm{~L}$. The MBfR contained a bundle of 60 hollow-fiber membranes (Watercode Company, Guangzhou, China) with the pore size of $0.02 \mu \mathrm{m}$. The reactor was $64 \mathrm{~cm}$ in height and the fiber surface area was $0.28 \mathrm{~m}^{2}$. The Figure 1 shows the schematic of the MBfR used in this study.

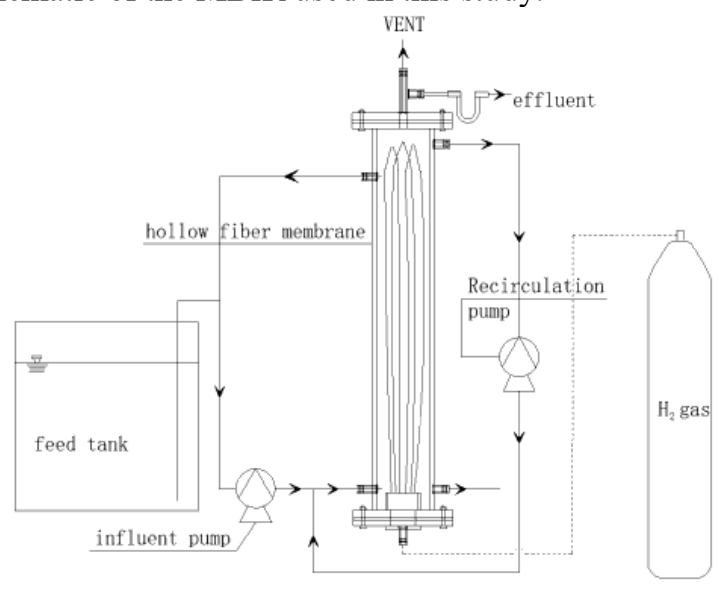

Fig. 1. Schematic of the hydrogen-based membrane biofilm reactor(MBfR)

\subsection{Experimental design}

We set up the nitrate reducing and perchlorate reducing MBfR in different conditions through stages 1-8, tap water blank forming biofilm sludge (KM), domesticated sludge in MBfR (XN), forming biofilm sludge in MBfR with a

\footnotetext{
*Corresponding author: 643507236@qq.com
} 
single $\mathrm{BrO}_{3}{ }^{-}$at $1 \mathrm{mg} / \mathrm{L}(\mathrm{BM})$ and forming biofilm sludge in MBfR at a concentration of $1 \mathrm{mg} / \mathrm{L}$ at a single $\mathrm{ClO}_{4}{ }^{-}$ (GM), setting the concentration of $\mathrm{BrO}_{3}^{-}$and $\mathrm{ClO}_{4}^{-}$to $1 \mathrm{mg} / \mathrm{L}$, changing the concentration of $\mathrm{NO}_{3}^{-}-\mathrm{N}$ in the influent $(1.5,2.5,5,10 \mathrm{mg} / \mathrm{L})$, and taking the biofilm sample attached to the hollow fiber membrane (BGM-1.5, BGM-2.5, BGM-5, BGM-10), respectively. The operating conditions of each stage are listed in Table 1.

Table 1. Conditions for culturing microorganisms.

\begin{tabular}{|c|c|c|c|c|}
\hline $\begin{array}{c}\text { Sam-ple } \\
\text { num-ber }\end{array}$ & Operat-ion time (d) & $\begin{array}{c}\text { Influent concent-ration } \\
\text { of } \mathrm{NO}_{3}^{-}-\mathrm{N}(\mathrm{mg} / \mathrm{L})\end{array}$ & $\begin{array}{c}\text { Influent concent-ration } \\
\text { of } \mathrm{BrO}_{3}^{-}(\mathrm{mg} / \mathrm{L})\end{array}$ & $\begin{array}{c}\text { Influent concent-ration } \\
\text { of } \mathrm{ClO}_{4}^{-}\left(\mathrm{mg}^{-}\right)^{-}\end{array}$ \\
\hline $\mathrm{KM}$ & $52(0-52)$ & 1.5 & - & - \\
\hline $\mathrm{XN}$ & $35(53-87)$ & 10.0 & - & - \\
\hline BM & $31(88-118)$ & 5.0 & 1.0 & 1.0 \\
\hline GM & $32(119-150)$ & 5.0 & 1.0 & 1.0 \\
\hline BGM-1.5 & $33(151-183)$ & 1.5 & 1.0 & 1.0 \\
\hline BGM-2.5 & $33(184-216)$ & 2.5 & 1.0 & 1.0 \\
\hline BGM-5 & $32(217-248)$ & 5.0 & 1.0 & 1.0 \\
\hline BGM-10 & $35(249-283)$ & 10 & - & - \\
\hline
\end{tabular}

Notes: Other experimental conditions are hydrogen pressure is $0.04 \mathrm{MPa}, \mathrm{HRT}$ is $15 \mathrm{~h}$, and initial $\mathrm{pH}$ is 7.0 .

The original sludge(YN), and the biofilm samples attached to the hollow fiber membrane during the stabilization period of each stage (KM, XM, BM, GM, BGM-1.5, BGM-2.5, BGM-5, BGM-10), each taken 1 part, using the kit to measure enzymes activity and highthroughput metagenomic microbial sequencing method to detect it, analyzing the microbial enzyme activity, and selecting the OTU clustering results in the overall abundance of the sequence for analysis to investigate the changes of the microbial population structure in the biofilm under the influence of $\mathrm{NO}_{3}{ }^{-}-\mathrm{N}$ before and after acclimation.

\section{Results and Discussion}

The biofilm on the outer surface of the hollow fiber membrane was sampled 8 times in total. Table 2 shows the specific sampling time and the operating con-ditions as well as the water quality characteristics of the reactor at the time of sampling.

Table 2. Water quality parameters and operational conditions at biofilm sampling time

\begin{tabular}{|c|c|c|c|c|c|c|c|c|}
\hline & $\mathrm{KM}$ & $\mathrm{XN}$ & $\mathrm{BM}$ & GM & $\begin{array}{c}\text { BGM- } \\
1.5\end{array}$ & $\begin{array}{c}\text { BGM- } \\
2.5\end{array}$ & BGM-5 & $\begin{array}{c}\text { BGM- } \\
10\end{array}$ \\
\hline Sampling time (d) & 52 & 87 & 118 & 150 & 183 & 216 & 248 & 283 \\
\hline Electron acceptor & $\mathrm{NO}_{3}{ }^{-}-\mathrm{N}$ & $\mathrm{NO}_{3}^{-}-\mathrm{N}$ & $\begin{array}{c}\mathrm{BrO}_{3}^{-} \\
\mathrm{NO}_{3}^{-}-\mathrm{N}\end{array}$ & $\begin{array}{c}\mathrm{ClO}_{4}^{-} \\
\mathrm{NO}_{3}^{-}-\mathrm{N}\end{array}$ & \multicolumn{4}{|c|}{$\mathrm{BrO}_{3}{ }^{-}, \mathrm{ClO}_{4}^{-}, \mathrm{NO}_{3}-\mathrm{N}$} \\
\hline $\begin{array}{l}\text { Influent concentration of } \\
\mathrm{NO}_{3}{ }^{-}-\mathrm{N}(\mathrm{mg} / \mathrm{L})\end{array}$ & 1.5 & 10 & 5 & 5 & 1.5 & 2.5 & 5 & 10 \\
\hline $\begin{array}{l}\text { Influent concentration of } \\
\mathrm{BrO}_{3}-(\mathrm{mg} / \mathrm{L})\end{array}$ & - & - & 1 & - & 1 & 1 & 1 & 1 \\
\hline $\begin{array}{c}\text { Influent concentration of } \\
\mathrm{ClO}_{4}^{-}(\mathrm{mg} / \mathrm{L})\end{array}$ & - & - & - & 1 & 1 & 1 & 1 & 1 \\
\hline hydrogen pressure (MPa) & 0.04 & 0.04 & 0.04 & 0.04 & 0.04 & 0.04 & 0.04 & 0.04 \\
\hline HRT $(\mathrm{h})$ & 15 & 15 & 15 & 15 & 15 & 15 & 15 & 15 \\
\hline $\begin{array}{l}\text { effluence concentration of } \\
\mathrm{NO}_{3}{ }^{-}-\mathrm{N}(\mathrm{mg} / \mathrm{L})\end{array}$ & ND & 0.31 & ND & ND & ND & ND & 0.23 & 0.35 \\
\hline $\begin{array}{l}\text { effluence concentration of } \\
\mathrm{BrO}_{3}{ }^{-}(\mathrm{mg} / \mathrm{L})\end{array}$ & - & - & ND & - & 0.01 & ND & 0.57 & 0.67 \\
\hline $\begin{array}{l}\text { effluence concentration of } \\
\mathrm{ClO}_{4}^{-}(\mathrm{mg} / \mathrm{L})\end{array}$ & - & - & - & ND & 0.02 & 0.01 & 0.55 & 0.62 \\
\hline
\end{tabular}

Notes: ND means not detected.

As can be seen from the above table, the sampling time is the last day of the reactor operation to each stable state, and the difference in working conditions is the time of electron acceptor (pollutant) addition. According to the water quality characteristics in the table, the removal effect of the reactor on various pollutants is obviously different under different working conditions.

\subsection{The effect of key enzymes activity in hydrogen autotrophic microorganisms}

Compared with the original sludge (YN), the tap water blank forming biofilm sludge $(\mathrm{KM})$ of the tap water has a significantly reduced denitrifying enzyme activity caused by the presence of heterotrophic denitrifying bacteria in the original sludge (YN), and the tap water blank forming biofilm sludge (KM) is an autotrophic type of bacteria. With the reducing of the biomass, the enzyme activity is being lowered Figure 2. On this basis, $10 \mathrm{mg} / \mathrm{L}$ domesticated sludge $(\mathrm{XN})$ was continuously added, the biomass of autotrophic denitrifying bacteria increased, and the activity of denitrifying enzyme upwarded, but a reduction was found in the activity of nitrate reductase, which indicates that the activity of nitrite reductase was significantly enhanced. The denitrifying enzyme and nitrate reductase activities of domesticated sludge (XN) at 
a concentration of $10 \mathrm{mg} / \mathrm{L}$ of $\mathrm{NO}_{3}{ }^{-} \mathrm{N}$ were $226.87 \mathrm{U} / \mathrm{L}$ and $70.98 \mathrm{U} / \mathrm{L}$, the two enzyme activities for simultaneous degradation of $\mathrm{BrO}_{3}^{-}$and $\mathrm{ClO}_{4}^{-}$(BGM-10) at the same $\mathrm{NO}_{3}{ }^{-}-\mathrm{N}$ concentration were $343.47 \mathrm{U} / \mathrm{L}$ and $76.67 \mathrm{U} / \mathrm{L}$, denitrifying enzyme activity was significantly improved, and nitrate reductase activity had no essencial change, which indicated that the addition of $\mathrm{BrO}_{3}{ }^{-}$and $\mathrm{ClO}_{4}{ }^{-}$had a little effect on nitrate reductase activity, but had a strong effect on denitrification enzyme activity. At the same time, the denitrifying enzyme activities of single degradation of $\mathrm{BrO}_{3}^{-}(\mathrm{BM})$ and $\mathrm{ClO}_{4}^{-}(\mathrm{GM})$ under the condition of $\mathrm{NO}_{3}^{-}-$ $\mathrm{N}$ concentration of $5 \mathrm{mg} / \mathrm{L}$ were $165.11 \mathrm{U} / \mathrm{L}$ and 158.02 $\mathrm{U} / \mathrm{L}$, and the denitrifying enzyme activity of $\mathrm{BrO}_{3}{ }^{-}$and $\mathrm{ClO}_{4}^{-}$(BGM-5) was $317.58 \mathrm{U} / \mathrm{L}$, which was significantly lower than the same concentration of $\mathrm{NO}_{3}^{-}-\mathrm{N}$, which proved that a part of denitrifying enzyme acts to reduce $\mathrm{BrO}_{3}{ }^{-}$and $\mathrm{ClO}_{4}{ }^{-}$. Past studies have shown that most of the $\mathrm{ClO}_{4}^{-}$reducing bacteria belong to denitrifying bacteria[12,13] and $\mathrm{BrO}_{3}^{-}$can be cometabolized by denitrifying enzyme or $\mathrm{ClO}_{4}^{-}$reductase to produce nontoxic $\mathrm{Br}^{-}$under denitri-fication or $\mathrm{ClO}_{4}^{-}$reduction conditions[14,15], similar to this research. The sludge enzyme activities of simultaneous degradation of $\mathrm{BrO}_{3}{ }^{-}$ and $\mathrm{ClO}_{4}{ }^{-}$under different $\mathrm{NO}_{3}{ }^{-}-\mathrm{N}$ concentrations showed that the activities of denitrifying enzyme and nitrate reductase increased linearly with the increase of $\mathrm{NO}_{3}{ }^{-}-\mathrm{N}$ concentration

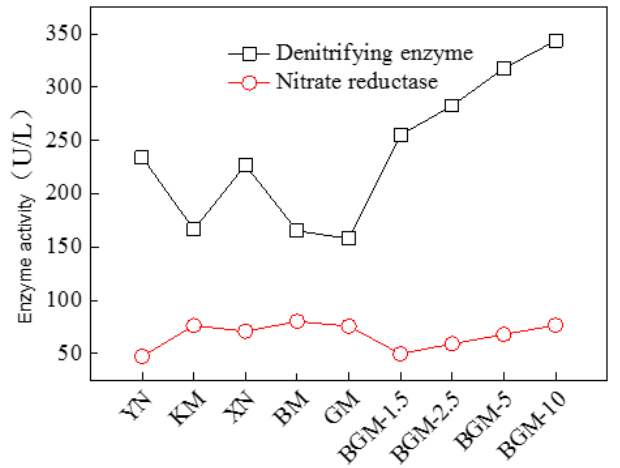

Fig. 2. Key enzymes activities of hydrogen autotrophic microorganisms

\section{Conclusion}

A hydrogen-based membrane biofilm reactor (MBfR) was operated for over 283 days. 8 different stages of MBfR were distributed to caltivate microorganisms. Key finding can be summarized as follows.

When $\mathrm{BrO}_{3}{ }^{-}$and $\mathrm{ClO}_{4}{ }^{-}$were degraded in the case of the same concentration of $\mathrm{NO}_{3}{ }^{-}-\mathrm{N}$ simultaneously, the activity of denitrifying enzyme was significantly greater than that of single degradation of one pollutant, but nitrate reductase activity was not significantly changed, indicating that some denitrifying enzymes had the effect of degrading $\mathrm{BrO}_{3}{ }^{-}$and $\mathrm{ClO}_{4}{ }^{-}$; with the increase of $\mathrm{NO}_{3}^{-}-$ $\mathrm{N}$ concentration, the activities of denitrifying enzyme and nitrate reductase were significantly increased.

\section{Acknowledgement}

This work was financially supported by the Program for the National Science Foundation of China (51638006).

\section{Reference}

1. M.C. Ziv-El, B.E. Rittmann, Water Research., 43, 173-181 (2009)

2. R. Nerenberg, Curr. Opin. Biotechnol., 38, 131-136 (2016)

3. S.Q. Xia, X. Xu, C. Zhou, C. Wang, L. Zhou, B.E. Rittmann, Chem. Eng. J., 290, 154-160 (2016)

4. C. Zhou, A. Ontiveros-Valencia, Z. Wang, J. Maldonado, B.E. Rittmann, Environ. Sci. Technol., 50, 2546-2555 (2016)

5. C.Y. Lai, X. Yang, Y. Tang, B.E. Rittmann H.P. Zhao, Environ. Sci. Technol., 48, 3395-3402 (2014)

6. K.J. Martin, R. Nerenberg, Bioresour. Technol., 122, 83-94 (2012)

7. Y. Hu, H. Cheng, Environ. Develop., 8, 57-73 (2013)

8. H.C. Shin, D.H. Ju, B.S. Jeon, O. Choi, H.W. Kim, Y. Um, PLOS ONE, 10 (2015)

9. J. Chung, X. Li, B.E. Rittmann, Chemosphere, 65, 2434 (2006)

10. J. Chung, R. Nerenberg, B.E. Rittmann, Water Research, 40, 1634-1642 (2006)

11. R. Nerenberg, B.E. Rittmann, I. Najm, J. Am. Water Works Assoc., 94, 103-114 (2002)

12. J. Chung, R. Krajmalnik-Brown, B.E. Rittmann Environ. Sci. Technol., 42, 477-483 (2008)

13. C.G. Van Ginkel, B.J. Middelhuis, F. Spijk, W.R. Abma, J. Ind. Microbiol. Biotechnol., 32, 1-6 (2005)

14. R. Butler, S. Ehrenberg, A.R. Godley, R. Lake, L. Lytton, E. Cartmell, Sci. Total Environ., 366, 12-20 (2006)

15. S. Demirel, I. UyaniK, A. Yurtsever, Celikten, Hakan, D. Ucar, CLEAN-Soil, Air, Water, 42, 1185-1189 (2014) 